\title{
3D ordered mesoporous cobalt ferrite phosphides for overall water splitting
}

\author{
Yarong Huang, Menggang Li, Weiwei Yang ${ }^{*}$, Yongsheng $\mathrm{Yu}^{*}$ and Sue Hao
}

\begin{abstract}
Developing low-cost and earth-abundant electrocatalysts with high performance for electrochemical water splitting is a challenging issue. Herein, we report a facile and effective way to fabricate three-dimension (3D) ordered mesoporous $\mathrm{Co}_{1-x} \mathrm{Fe}_{x} \mathrm{P}(x=0,0.25,0.5,0.75)$ electrocatalyst. Benefiting from 3D ordered mesoporous pore channels and composition optimization, the $\mathrm{Co}_{0.75} \mathrm{Fe}_{0.25} \mathrm{P}$ exhibits excellent electrocatalytic activities with low overpotentials of 270 and $209 \mathrm{mV}$ at $10 \mathrm{~mA} \mathrm{~cm}^{-2}$ for oxygen evolution reaction (OER) and hydrogen evolution reaction (HER), respectively, in the alkaline electrolyte along with a durable electrochemical stability. In addition, as both the cathode and anode, the $\mathrm{Co}_{0.75} \mathrm{Fe}_{0.25} \mathrm{P}$ also exhibits superior electrolysis water splitting performance with only an applied voltage of $1.63 \mathrm{~V}$ to attain a current density of $10 \mathrm{~mA} \mathrm{~cm}$ without obvious decay for $18 \mathrm{~h}$, indicating that the $\mathrm{Co}_{0.75} \mathrm{Fe}_{0.25} \mathrm{P}$ is an efficient electrocatalyst for overall water splitting.
\end{abstract}

Keywords: cobalt ferrite phosphides, 3D ordered mesoporous structure, highly efficient electrocatalysts, water splitting

\section{INTRODUCTION}

Electrochemical water splitting is generally accepted as an effective way for producing hydrogen and oxygen via the anodic oxygen evolution reaction (OER) and cathodic hydrogen evolution reaction (HER) [1-5]. Traditionally, $\mathrm{IrO}_{2} / \mathrm{RuO}_{2}$ and $\mathrm{Pt} / \mathrm{C}$ have been recognized as the most state-of-the-art electrocatalysts for the OER and HER, respectively. However, the natural scarcity and high price of these noble metal-based materials greatly hinder their scale-up practical implementations [6,7]. Therefore, extensive studies have been performed to construct economical and earth-abundant catalysts as alternative candidates toward high-efficiency water electrolysis. Transition metal (Co, Ni, Fe, Mn) oxides [8], sulfides [9$11]$, phosphides [12,13], selenides [14,15], and perovskites
[16] have been exploited as electrocatalysts for water electrolysis and impressive progress has been achieved. Particularly, transition metal phosphides attract more attention attributed to their low cost, natural abundance, and superior catalytic performance [17-21]. Compared with mono-metal phosphides, bi-metal phosphides have been proved to show richer faradaic redox and higher electrical conductivity and stability owing to their electronic structure optimization and synergistic effect [2224]. Thus, it is extremely worthwhile but challenging to further develop efficient bi-metal phosphides catalysts for overall water splitting.

In addition, structural and morphological engineering of electrocatalysts is a vital route to improve the catalytic activity for overall water splitting. Compared with zero dimensional (0D), 1D, and 2D nanocatalysts toward overall water splitting, 3D nanostructures generally possess large specific surface areas, which can be advantageous as the electrocatalysts through exposing abundant active sites [25-28]. Recently, Cheng et al. [29] developed $\mathrm{Ni}$-Fe (hydr)oxide@NiCu electrocatalysts with 3D hierarchical nanoarchitectures with superior activity, owing to the large surface and synergistic effects from the unique structure. Fan et al. [30] assembled 3D core-shell $\mathrm{NiFeCr}$ metal/metal hydroxide on the $\mathrm{Cu}$ nanorods, and yielded a current density of $10 \mathrm{~mA} \mathrm{~cm}^{-2}$ with a lower overpotential of $200 \mathrm{mV}$ on the OER electrode, demonstrating that nanostructure regulation and electronic structure modulation could improve the catalytic kinetics effectively. Zhou et al. [31] reported a $\mathrm{Ni} / \mathrm{Ni}_{2} \mathrm{P}$ inverse opal bifunctional electrode, which showed robust catalytic performance and long-term stability attributed to the $3 \mathrm{D}$ microporous structure. Transition metal phosphides with mesoporous structure show more structure advantages in overall water splitting due to their large surface area and high porosity [32]. In addition, interconnected channels

MIIT Key Laboratory of Critical Materials Technology for New Energy Conversion and Storage, School of Chemistry and Chemical Engineering, Harbin Institute of Technology, Harbin 150001, China

* Corresponding authors (emails: yangww@hit.edu.cn (Yang W); ysyu@hit.edu.cn (Yu Y)) 
of mesoporous structure have been regarded as an effective way to improve the charge transfer and mass transfer [33-35]. Therefore, constructing well-ordered mesoporous 3D nanostructures with interconnected channels is an effective way to further enhance the catalytic activity of bi-metal phosphides for overall water splitting.

In this work, we prepared 3D ordered mesoporous $\mathrm{Co}_{1-x} \mathrm{Fe}_{x} \mathrm{P}$ with uniformly interconnected channels and introduced different proportion of iron to obtain electrocatalysts with high performance for overall water splitting through structural and compositional engineering. The optimized 3D ordered mesoporous $\mathrm{Co}_{0.75} \mathrm{Fe}_{0.25} \mathrm{P}$ electrocatalyst exhibited remarkable catalytic activity for both OER and HER in alkaline electrolyte and obtained the overpotentials of $270 \mathrm{mV}$ (OER) and $209 \mathrm{mV}$ (HER) at a current density of $10 \mathrm{~mA} \mathrm{~cm}$. The 3D ordered mesoporous $\mathrm{Co}_{0.75} \mathrm{Fe}_{0.25} \mathrm{P}$ as the catalyst for overall water splitting achieved a current density of $10 \mathrm{~mA} \mathrm{~cm}^{-2}$ at a voltage of $1.63 \mathrm{~V}$. This work provides a new avenue for the design and development of highly efficient $3 \mathrm{D}$ ordered mesoporous bi-metal phosphides electrocatalysts for overall water splitting.

\section{EXPERIMENTAL SECTION}

\section{Preparation of 3D mesoporous $\mathrm{Co}_{1-x} \mathrm{Fe}_{x} \mathrm{P}$}

$3 \mathrm{D}$ mesoporous $\mathrm{Co}_{1-x} \mathrm{Fe}_{x} \mathrm{P}$ was prepared via a facile nanocasting method. KIT- 6 was synthesized as previously reported [36]. Briefly, $3 \mathrm{~g}$ P123 was dissolved in $108 \mathrm{~mL}$ deionized water to form a homogeneous solution. $5 \mathrm{~mL}$ $\mathrm{HCl}$ was added and stirred vigorously until P123 was completely dissolved. Then $3 \mathrm{~g} n$-butanol was added to the solution and kept in a $35^{\circ} \mathrm{C}$ oil bath. After $1 \mathrm{~h}$ stirring, $6.45 \mathrm{~g}$ tetraethyl orthosilicate (TEOS) was added into the solution and stirred for $24 \mathrm{~h}$. Hydrothermal treatment $\left(100^{\circ} \mathrm{C}\right)$ was applied for $24 \mathrm{~h}$. After hydrothermal process, the product was precipitated and collected by filtration. The solid product was put into a crucible and calcinated at $550^{\circ} \mathrm{C}$ for $6 \mathrm{~h}$.

KIT-6-100 (0.5 g) was immersed into $4 \mathrm{~mL}$ ethanol solution containing $0.8 \mathrm{~mol} \mathrm{~L}^{-1}$ metal precursor (Co$\left(\mathrm{NO}_{3}\right)_{2} \cdot 6 \mathrm{H}_{2} \mathrm{O}\left(99 \%\right.$, Aladdin) and $\mathrm{Fe}\left(\mathrm{NO}_{3}\right)_{3} \cdot 6 \mathrm{H}_{2} \mathrm{O}(99 \%$, Aladdin) mixed with different ratios). The mixture was stirred and heated at $50^{\circ} \mathrm{C}$ overnight until the solvent was completely evaporated. Afterwards, the dry powder was calcinated at $200^{\circ} \mathrm{C}$ for $6 \mathrm{~h}$. The obtained powder was annealed at $500^{\circ} \mathrm{C}$ for $5 \mathrm{~h}$ after the repeated impregnation process. Then, the resulting product was mixed with $\mathrm{NaH}_{2} \mathrm{PO}_{2} \cdot \mathrm{H}_{2} \mathrm{O}$ (weight ratio: 1:10) and calcinated at $325^{\circ} \mathrm{C}$ for $2 \mathrm{~h}$ under Ar atmosphere. The final product was obtained after etching by $5 \%$ HF solution for $12 \mathrm{~h}$ and washing with deionized water for three times. The schematic of preparation process was illustrated in Fig. 1a.

\section{Characterization}

Transmission electron microscopy (TEM) was conducted on a JEOL JEM-1400. High resolution TEM (HRTEM) images were obtained using a FEI Tecnai G2 F30 at $300 \mathrm{kV}$. X-ray diffraction (XRD) patterns were recorded using a PANanalytical $\mathrm{X}^{\prime}$ Pert powder with $\mathrm{Cu} \mathrm{Ka}$ radiation $(\lambda=1.5418 \AA)$. The specific surface areas and pore diameter distributions of the catalysts were investigated at $77 \mathrm{~K}$ in $\mathrm{N}_{2}$ on a Beishide $3 \mathrm{H}-2000 \mathrm{PS} 1 \mathrm{Gas}$ Sorption and Porosimetry system by Brunauner-EmmetTeller (BET) and Barrett-Joyner-Halenda (BJH) methods. $\mathrm{X}$-ray photoelectron spectroscopic (XPS) measurements were conducted on a Perkin-Elmer PHI 5000C ESCA using twin anode $\mathrm{Mg} \mathrm{Ka}(1253.6 \mathrm{eV})$ radiation.

\section{Electrochemical measurements}

Electrocatalytic properties were tested on a workstation (CHI 760E). $5 \mathrm{mg}$ as-prepared materials or commercial $\mathrm{RuO}_{2}$ or $\mathrm{Pt} / \mathrm{C}$ were dispersed in a mixture of $750 \mu \mathrm{L}$ distilled water, $250 \mu \mathrm{L}$ isopropanol and $20 \mu \mathrm{L}$ Nafion solution ( $5 \mathrm{wt} \%$, Alfa Aesar). After sonication for $30 \mathrm{~min}$, $5 \mu \mathrm{L}$ of catalyst ink was dropped on the surface of the

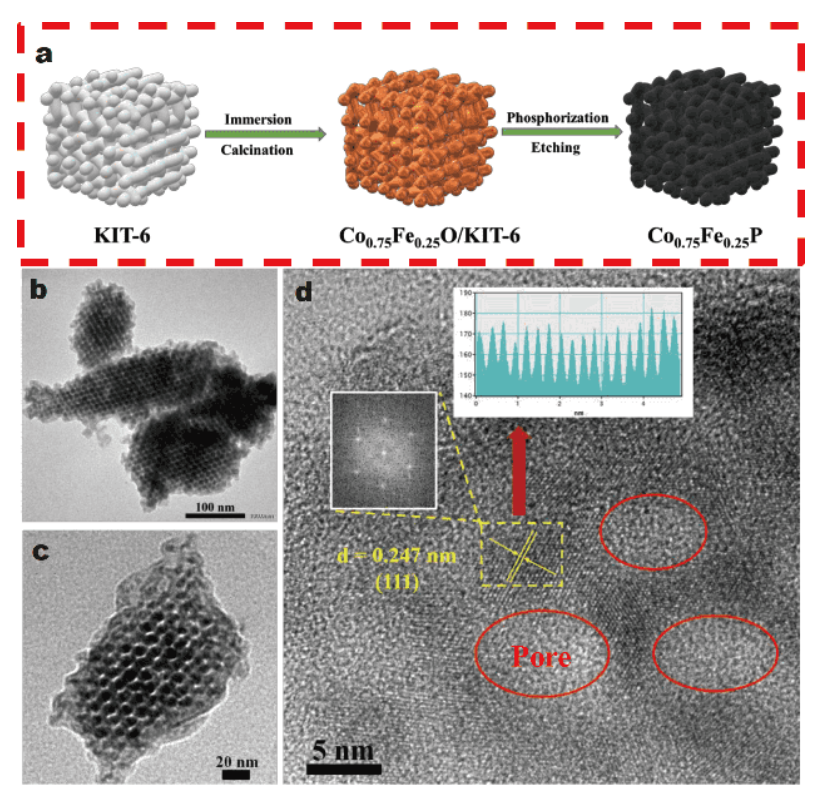

Figure 1 (a) Schematic illustration of the preparation process of $\mathrm{Co}_{0.75^{-}}$ $\mathrm{Fe}_{0.25} \mathrm{P}$; (b) and (c) TEM images with different magnification; (d) HRTEM image for $\mathrm{Co}_{0.75} \mathrm{Fe}_{0.25} \mathrm{P}$. 
glass carbon electrode (GCE) and dried at room temperature. The polished GCE (surface area: $0.07 \mathrm{~cm}^{2}$ ), Pt wire (a graphite rod) and saturated $\mathrm{Ag} / \mathrm{AgCl}$ were applied as the working electrode, counter electrode and reference electrode, respectively. The loading amount of catalysts was $0.35 \mathrm{mg} \mathrm{cm}^{-2}$. Every electrode was first activated by cyclic voltammetry (CV) until the stable performance exhibited. The calibration of the potentials was based on $E_{\mathrm{RHE}}=E_{\mathrm{Ag} / \mathrm{AgCl}}+0.197+0.059 \mathrm{pH}, \mathrm{pH}=13.7$, and linear sweep voltammetry (LSV) with a scan rate of $5 \mathrm{mV} \mathrm{s}^{-1}$ was used to get the polarization curves without $i R$ compensation. Electrochemical impedance spectroscopy (EIS) was obtained at $1.5 \mathrm{~V} v s$. reversible hydrogen electrode (RHE) for the OER in the frequency region of 0.01$100 \mathrm{kHz}$ with the amplitude of $5 \mathrm{mV}$. The electrochemical active surface areas (ECSAs) were determined at different scan rates of 2, 4, 6, 8, and $10 \mathrm{mV} \mathrm{s}^{-1}$ (potential region: $1.2-1.3 \mathrm{~V}$ vs. RHE). Amperometric $i-t$ curves (durability measurements) were conducted at 10 and $40 \mathrm{~mA} \mathrm{~cm}^{-2}$ for OER, $10 \mathrm{~mA} \mathrm{~cm}^{-2}$ for HER and overall water splitting. $\mathrm{CV}$ was used for cycling test at $100 \mathrm{mV} \mathrm{s}^{-1}$ for $1000 \mathrm{cy}$ cles. The electrochemical activity of overall water splitting setup applied with $\mathrm{Co}_{0.75} \mathrm{Fe}_{0.25} \mathrm{P}$ as both anode and cathode, was performed through LSV with a scanning rate of $5 \mathrm{mV} \mathrm{s}^{-1}$. The loading amount of catalysts for overall water splitting was $1 \mathrm{mg} \mathrm{cm}^{-2}$.

\section{RESULTS AND DISCUSSION}

KIT-6 was first prepared according to the previous report and used as a hard template for subsequent synthesis (Fig. S1a). In view of the highly interconnectivity microstructure of mesoporous channels on the KIT-6, a perfectly replicated nanocast material can be shaped [3740]. Therefore, in order to obtain 3D ordered mesoporous cobalt ferrite phosphides, the immersion, calcination, phosphatization and etching processes were performed (Fig. 1a). By changing the ratio of precursors, cobalt ferrite phosphides with different compositions were obtained. Inductively coupled plasma optical emission spectrometry (ICP-OES) was further applied to analyze the compositions of products, and finally determined to be $\mathrm{Co}_{0.75} \mathrm{Fe}_{0.25} \mathrm{P}, \mathrm{Co}_{0.5} \mathrm{Fe}_{0.5} \mathrm{P}$, and $\mathrm{Co}_{0.25} \mathrm{Fe}_{0.75} \mathrm{P}$ (Table S1). It can be clearly seen that slit-like pores are well distributed among the entire $\mathrm{Co}_{0.75} \mathrm{Fe}_{0.25} \mathrm{P}$, as shown in Fig. 1b, c. All of these mesopores are well-ordered, revealing the faithful replication of the cubic structured KIT-6-100 template. Furthermore, the morphology and structure of different phosphides are not affected by the compositions of $\mathrm{Co}_{1-x} \mathrm{Fe}_{x} \mathrm{P}$ (Fig. S1b-d). HRTEM image further confirms its porous and the selected area electron diffraction
(SAED) pattern of $\mathrm{Co}_{0.75} \mathrm{Fe}_{0.25} \mathrm{P}$ clearly shows a well-resolved lattice fringe of $0.247 \mathrm{~nm}$ (Fig. 1d), ascribed to the (111) crystal plane of CoP [41].

The XRD patterns of $\mathrm{Co}_{1-x} \mathrm{Fe}_{x} \mathrm{P}$ with different $\mathrm{Co} / \mathrm{Fe}$ ratios are shown in Fig. 2a. The XRD patterns of $\mathrm{Co}_{0.75^{-}}$ $\mathrm{Fe}_{0.25} \mathrm{P}$ and $\mathrm{Co}_{0.5} \mathrm{Fe}_{0.5} \mathrm{P}$ exhibit diffraction peaks at $31.6^{\circ}$, $36.3^{\circ}, 46.2^{\circ}, 48.1^{\circ}$ and $56.7^{\circ}$, corresponding to the (011), (111), (112), (211) and (301) planes of CoP (PDF No. 290497). Further increasing the $\mathrm{Fe}$ composition, the diffraction peaks of $\mathrm{Co}_{0.25} \mathrm{Fe}_{0.75} \mathrm{P}$ appear at $40.2^{\circ}, 44.1^{\circ}, 47.3^{\circ}$, $52.9^{\circ}$ and $54.1^{\circ}$ which can be assigned to the (111), (201), (210), (002), and (300) crystal planes of $\mathrm{Fe}_{2} \mathrm{P}$ (PDF No. 27-1171). These results reveal that the $\mathrm{Co}_{1-x} \mathrm{Fe}_{x} \mathrm{P}$ with $x \leq 0.5$ features the crystal structure of CoP.

To investigate the specific surface area and the pore size distribution of the $\mathrm{Co}_{0.75} \mathrm{Fe}_{0.25} \mathrm{P}, \mathrm{N}_{2}$ adsorption-desorption measurement was performed at $77 \mathrm{~K}$ (Fig. 2b). The curve of the $\mathrm{Co}_{0.75} \mathrm{Fe}_{0.25} \mathrm{P}$ shows IV-type sorption isotherms, with hysteresis loops characteristic of mesoporous materials, consistent with the results of the TEM measurement. The specific surface area and pore volume of $\mathrm{Co}_{0.75} \mathrm{Fe}_{0.25} \mathrm{P}$ are $148 \mathrm{~m}^{2} \mathrm{~g}^{-1}$ and $0.56 \mathrm{~cm}^{3} \mathrm{~g}^{-1}$, respectively. Moreover, the pore size distribution (inset of Fig. 2b) of $\mathrm{Co}_{0.75} \mathrm{Fe}_{0.25} \mathrm{P}$ reveals a bimodal pore size distribution centered around 4 and $12 \mathrm{~nm}$. The unique 3D ordered mesoporous structure with high surface area and conjunct bimodal pores is expected to afford a larger electroactive surface area for efficient HER and OER, while providing sufficient channels for rapid mass transport [42].

The elemental composition and surface chemistry of the as-synthesized $\mathrm{Co}_{0.75} \mathrm{Fe}_{0.25} \mathrm{P}$ samples were studied by XPS. The full scan XPS spectrum of $\mathrm{Co}_{0.75} \mathrm{Fe}_{0.25} \mathrm{P}$ in Fig. $2 \mathrm{c}$ shows the coexistence of $\mathrm{Co}, \mathrm{Fe}, \mathrm{P}, \mathrm{C}$ and $\mathrm{O}$, wherein $\mathrm{C}$ and $\mathrm{O}$ originate from the superficial oxidation and contamination of the samples. In the high-resolution Co $2 \mathrm{p}$ spectra (Fig. 2d), 781.9 and $798.0 \mathrm{eV}$ are related to the oxide state binding energy of Co $2 \mathrm{p}_{3 / 2}$ and Co $2 \mathrm{p}_{1 / 2}$, while 778.9 and $793.9 \mathrm{eV}$ are assigned to $\mathrm{Co}-\mathrm{P}$ in $\mathrm{Co}_{0.75} \mathrm{Fe}_{0.25} \mathrm{P}$ and 786.5 and $802.7 \mathrm{eV}$ are corresponded with the satellite peak [43]. Similarly, the high-resolution Fe 2p spectra (Fig. 2e) of $\mathrm{Co}_{0.75} \mathrm{Fe}_{0.25} \mathrm{P}$ has two intense peaks at 706.5 and $719.4 \mathrm{eV}$, corresponding to $\mathrm{Fe}-\mathrm{P}$ [44]. The peaks located at $711.2,713.9,725.1$ and $730.4 \mathrm{eV}$ are assigned to the oxide state binding energy of $\mathrm{Fe} 2 \mathrm{p}_{3 / 2}$ and $\mathrm{Fe}$ $2 \mathrm{p}_{1 / 2}$, respectively $[45,46]$. In the XPS spectrum of P $2 \mathrm{p}$ (Fig. 2f), the binding energies of 128.6 and $129.5 \mathrm{eV}$ are ascribed to $\mathrm{P} 2 \mathrm{p}_{3 / 2}$ and $\mathrm{P} 2 \mathrm{p}_{1 / 2}$, respectively, which reveals that the $\mathrm{Co}, \mathrm{Fe}$ and $\mathrm{P}$ have strong electron interaction with each other. And the peak in P $2 p$ spectra at $133 \mathrm{eV}$ is 

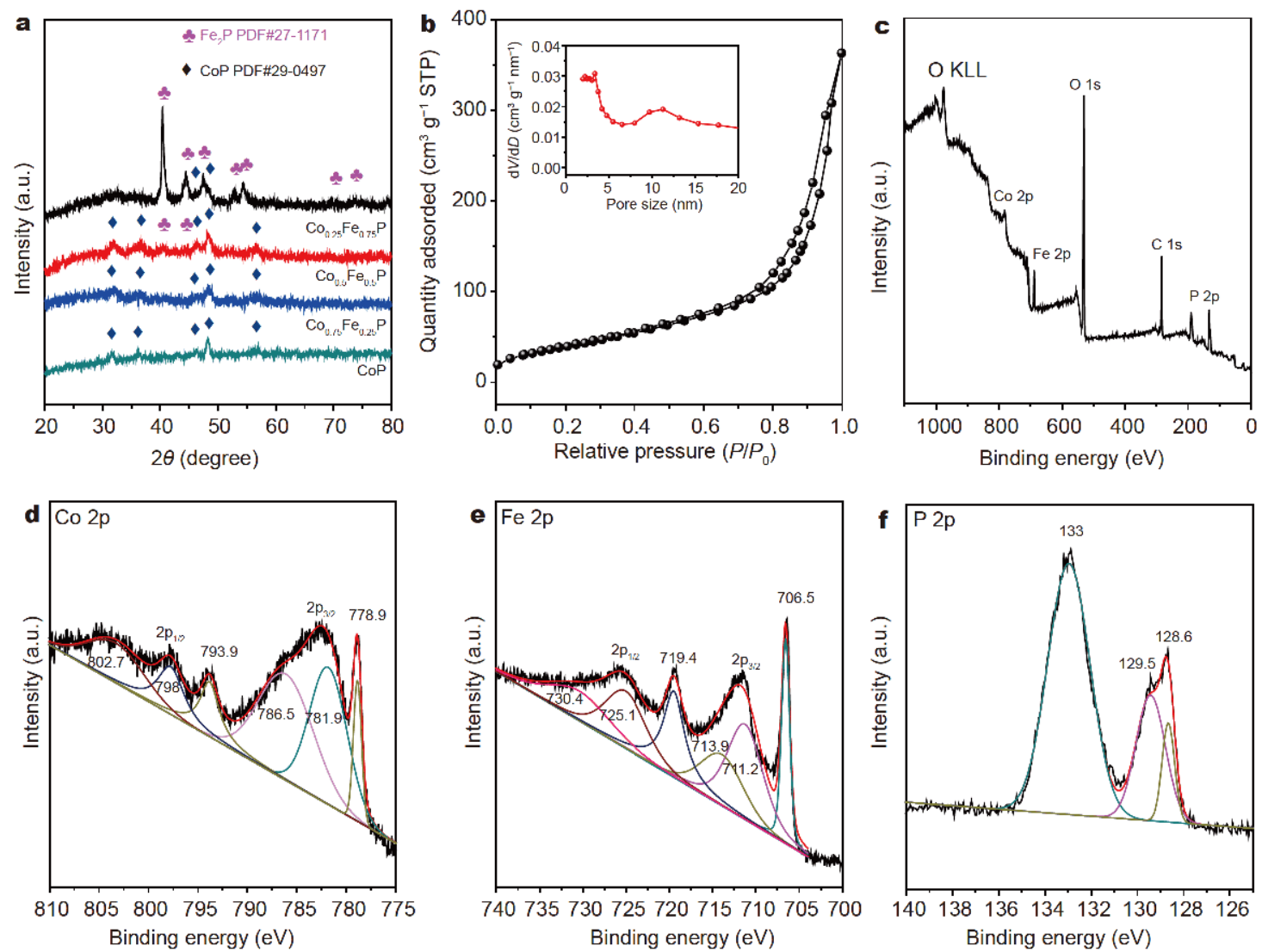

Figure 2 (a) XRD patterns of $\mathrm{Co}_{0.25} \mathrm{Fe}_{0.75} \mathrm{P}, \mathrm{Co}_{0.5} \mathrm{Fe}_{0.5} \mathrm{P}, \mathrm{Co}_{0.75} \mathrm{Fe}_{0.25} \mathrm{P}$ and $\mathrm{CoP}$, (b) $\mathrm{N}_{2}$ adsorption-desorption isotherms of the mesoporous $\mathrm{Co}_{0.75} \mathrm{Fe}_{0.25} \mathrm{P}$, and the inset is the corresponding pore size distributions, (c) XPS survey spectra of $\mathrm{Co}_{0.75} \mathrm{Fe}_{0.25} \mathrm{P}, \mathrm{XPS}$ spectra of Co $2 \mathrm{p}$ (d), Fe $2 \mathrm{p}$ (e) and P $2 \mathrm{p}$ (f).

ascribed to oxidized $\mathrm{P}$ species [47-49].

The electrocatalytic activities of the as-synthesized catalysts for OER were tested in $1.0 \mathrm{~mol} \mathrm{~L}^{-1} \mathrm{KOH}$ electrolyte using a three-electrode configuration. Fig. 3a exhibits the LSV polarization curves of $\mathrm{CoP}, \mathrm{Co}_{0.25} \mathrm{Fe}_{0.75} \mathrm{P}$, $\mathrm{Co}_{0.5} \mathrm{Fe}_{0.5} \mathrm{P}, \mathrm{Co}_{0.75} \mathrm{Fe}_{0.25} \mathrm{P}$ and commercial $\mathrm{RuO}_{2}$ with a scan rate of $5 \mathrm{mV} \mathrm{s}^{-1}$ and without $i R$ compensation. Obviously, $\mathrm{Co}_{0.75} \mathrm{Fe}_{0.25} \mathrm{P}$ exhibits the best OER performance among all the catalysts (Fig. 3b). Especially, to afford a current density of $10 \mathrm{~mA} \mathrm{~cm}^{-2}$, it only needs a small overpotential of $270 \mathrm{mV}\left(\mathrm{RuO}_{2}: 277 \mathrm{mV}\right)$. It was reported that Fe may have the positive role for OER since the doping of Fe may exert a partial-charge transfer activation effect on Co and improve the conductivity [50]. In addition, larger overpotentials of $319 \mathrm{mV}$ are required to achieve the same current density for CoP, which further demonstrates that the synergetic effect of $\mathrm{Co}$ and $\mathrm{Fe}$ in the catalyst. Furthermore, the overpotential of $\mathrm{Co}_{0.75} \mathrm{Fe}_{0.25} \mathrm{P}$ at a current density of $40 \mathrm{~mA} \mathrm{~cm}^{-2}$ is $316 \mathrm{mV}$, which is remarkably smaller than that of CoP $(370 \mathrm{mV}), \mathrm{Co}_{0.25} \mathrm{Fe}_{0.75} \mathrm{P}(398 \mathrm{mV}), \mathrm{Co}_{0.5} \mathrm{Fe}_{0.5} \mathrm{P}(347 \mathrm{mV})$ and $\mathrm{RuO}_{2}(470 \mathrm{mV})$, respectively (Fig. 3b). The corresponding Tafel slopes of $\mathrm{Co}_{1-x} \mathrm{Fe}_{x} \mathrm{P}$ samples with different $\mathrm{Co} / \mathrm{Fe}$ ratios given in Fig. $3 \mathrm{C}$ reveal that the $\mathrm{Co}_{0.75} \mathrm{Fe}_{0.25} \mathrm{P}$ possesses the smallest Tafel value of $48.2 \mathrm{mV} \mathrm{dec}^{-1}$. The extremely low Tafel slope reveals that the $\mathrm{Co}_{0.75} \mathrm{Fe}_{0.25} \mathrm{P}$ has a better reaction kinetics and faster charge transfer during the OER than other samples. Note that the overpotential of the as-prepared $\mathrm{Co}_{0.75} \mathrm{Fe}_{0.25} \mathrm{P}$ catalyst is much smaller than most of the state-of-the-art reported phosphidebased OER catalysts (Table S2).

Low charge-transfer resistance and abundant accessible active sites are indispensable for superior electrocatalytic performance. The electrochemical double layer capacitances $\left(C_{\mathrm{dl}}\right)$ and the resistance of different mesoporous cobalt ferrite phosphates were further investigated by $\mathrm{CV}$ under different scan rates (Fig. S2). The $C_{\mathrm{dl}}$ calculated from CVs of $\mathrm{Co}_{0.75} \mathrm{Fe}_{0.25} \mathrm{P}$ is $47.2 \mathrm{mF} \mathrm{cm}{ }^{-2}$, higher than the other phosphates catalysts, indicating that $\mathrm{Co}_{0.75} \mathrm{Fe}_{0.25} \mathrm{P}$ can exposure more catalytic active sites due to a large contact between the catalysts and electrolyte, which is beneficial to enhancing the catalytic activity for OER [51]. 

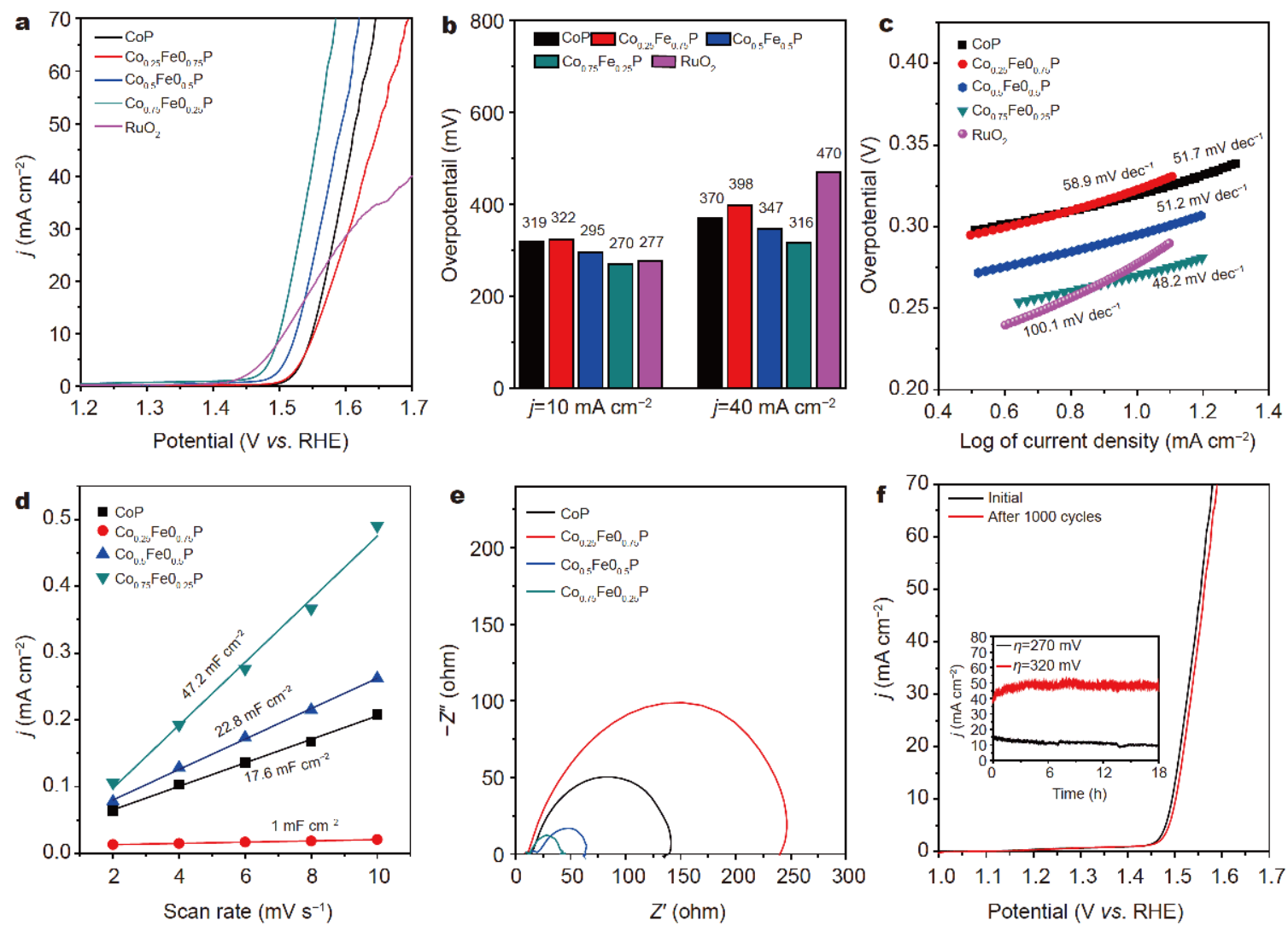

Figure 3 (a) LSV polarization curves, (b) overpotentials of current density of 10 and $40 \mathrm{~mA} \mathrm{~cm}^{-2}$, (c) corresponding Tafel slopes and (d) the capacitive current of $\mathrm{CoP}, \mathrm{Co}_{0.25} \mathrm{Fe}_{0.75} \mathrm{P}, \mathrm{Co}_{0.5} \mathrm{Fe}_{0.5} \mathrm{P}, \mathrm{Co}_{0.75} \mathrm{Fe}_{0.25} \mathrm{P}$ and $\mathrm{RuO}_{2}$ for OER in $1 \mathrm{~mol} \mathrm{~L}{ }^{-1} \mathrm{KOH}$ with a scan rate of $5 \mathrm{mV} \mathrm{s}$. (e) $\mathrm{Nyquist}^{-1}$ plots of different mesoporous phosphides at $1.5 \mathrm{~V}$ vs. RHE. (f) OER stability of $\mathrm{Co}_{0.75} \mathrm{Fe}_{0.25} \mathrm{P}$ after 1000 cycles of $\mathrm{CV}$, and the inset is the OER stability of $\mathrm{Co}_{0.75} \mathrm{Fe}_{0.25} \mathrm{P}$ for $18 \mathrm{~h}$ under the overpotential of 270 and $320 \mathrm{mV}$.

In addition, as shown in Fig. 3e, the impedance of the catalysts increases following the sequence of $\mathrm{Co}_{0.75} \mathrm{Fe}_{0.25} \mathrm{P}$, $\mathrm{Co}_{0.5} \mathrm{Fe}_{0.5} \mathrm{P}, \mathrm{CoP}, \mathrm{Co}_{0.25} \mathrm{Fe}_{0.75} \mathrm{P}$, consistent with the results of OER activity. The lowest resistance of $\mathrm{Co}_{0.75} \mathrm{Fe}_{0.25} \mathrm{P}$ implies that the additional appropriate electronic structures caused by the introduction of the $\mathrm{Fe}$ and the abundant 3D ordered mesoporous pore channels accelerate the mass and charge transfer, while facilitating the escape of the generated gas, which results in more favorable electrocatalytic kinetics. Durability was further assessed to illustrate the excellent OER performance of $\mathrm{Co}_{0.75} \mathrm{Fe}_{0.25} \mathrm{P}$ (Fig. 3f). The overpotential of $\mathrm{Co}_{0.75} \mathrm{Fe}_{0.25} \mathrm{P}$ after 1000 cycles increases slightly, demonstrating the superior stability. On the other hand, overpotentials at $270 \mathrm{mV}\left(10 \mathrm{~mA} \mathrm{~cm}^{-2}\right)$ and $320 \mathrm{mV}\left(40 \mathrm{~mA} \mathrm{~cm}^{-2}\right)$ were also applied to carry out the stability test. The current density of $\mathrm{Co}_{0.75} \mathrm{Fe}_{0.25} \mathrm{P}$ at both 270 and $320 \mathrm{mV}$ maintain high efficiency electrolysis for at least $18 \mathrm{~h}$, further suggesting the excellent durability of mesoporous $\mathrm{Co}_{0.75^{-}}$ $\mathrm{Fe}_{0.25} \mathrm{P}$ during the OER. To further understand the ex- cellent OER activity source of the $\mathrm{Co}_{0.75} \mathrm{Fe}_{0.25} \mathrm{P}$, XPS measurement was conducted to compare the chemical state with pure CoP (Fig. S3). The binding energy of Co $2 \mathrm{p}_{3 / 2}$ in $\mathrm{Co}_{0.75} \mathrm{Fe}_{0.25} \mathrm{P}(778.9 \mathrm{eV})$ is higher than that in CoP $(778.6 \mathrm{eV})$, indicating that the incorporation of $\mathrm{Fe}$ causes a significant electronic structure modification and faster charge transfer, which is favorable to improve electronic behaviors and optimize reaction process for OER [52].

The HER performance of the as-synthesized $\mathrm{Co}_{1-x} \mathrm{Fe}_{x} \mathrm{P}$ with different $\mathrm{Co} / \mathrm{Fe}$ ratios were also characterized under the same electrolyte conditions $\left(1 \mathrm{~mol} \mathrm{~L}^{-1} \mathrm{KOH}\right)$. LSV curves reveal that $\mathrm{Co}_{0.75} \mathrm{Fe}_{0.25} \mathrm{P}$ has the lowest overpotential, and the HER activities are also following the same order as that of OER. To achieve a current density of $10 \mathrm{~mA} \mathrm{~cm}{ }^{-2}$, the $\mathrm{Co}_{0.75} \mathrm{Fe}_{0.25} \mathrm{P}$ requires an overpotential of $209 \mathrm{mV}$, lower than other catalysts, $278 \mathrm{mV}$ for CoP, $319 \mathrm{mV}$ for $\mathrm{Co}_{0.25} \mathrm{Fe}_{0.75} \mathrm{P}$ and $253 \mathrm{mV}$ for $\mathrm{Co}_{0.5} \mathrm{Fe}_{0.5} \mathrm{P}$, and higher than $\mathrm{Pt} / \mathrm{C}(115 \mathrm{mV})$ at $\eta_{10}$ (Fig. $\left.4 \mathrm{~b}\right)$. Meanwhile, the Tafel slope of the $\mathrm{Co}_{0.75} \mathrm{Fe}_{0.25} \mathrm{P}$ is $55.5 \mathrm{mV} \mathrm{dec}{ }^{-1}$, which is remarkably smaller than that of $\mathrm{CoP}\left(66.1 \mathrm{mV} \mathrm{dec}^{-1}\right)$, 

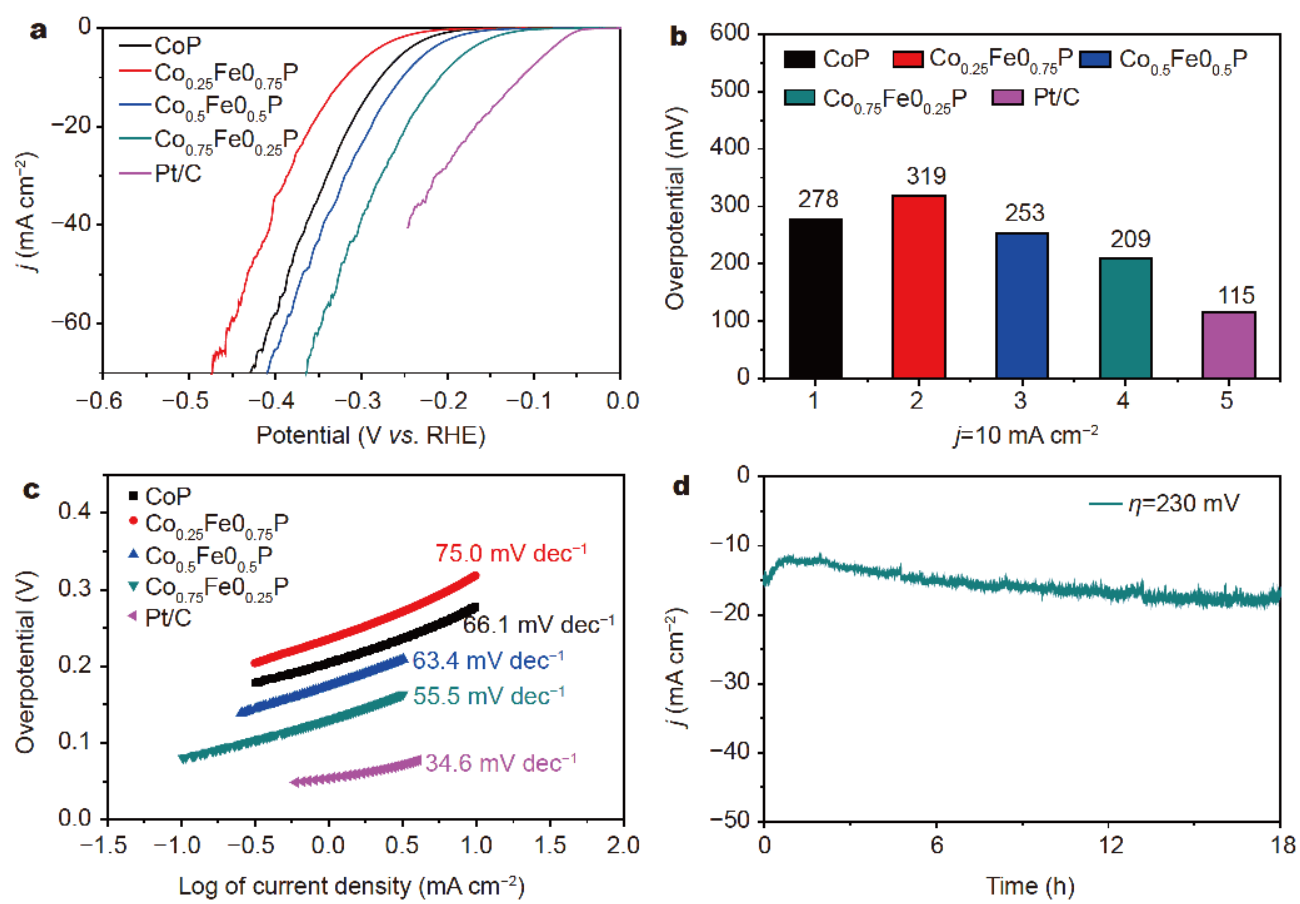

Figure 4 (a) LSV polarization curves, (b) overpotentials of current density of $10 \mathrm{~mA} \mathrm{~cm}{ }^{-2}$, (c) corresponding Tafel slopes of CoP, Co ${ }_{0.25} \mathrm{Fe}_{0.75} \mathrm{P}$, $\mathrm{Co}_{0.5} \mathrm{Fe}_{0.5} \mathrm{P}, \mathrm{Co}_{0.75} \mathrm{Fe}_{0.25} \mathrm{P}$ and $\mathrm{Pt} / \mathrm{C}$ for HER in $1 \mathrm{~mol} \mathrm{~L}{ }^{-1} \mathrm{KOH}$. (d) HER stability of $\mathrm{Co}_{0.75} \mathrm{Fe}_{0.25} \mathrm{P}$ for $18 \mathrm{~h}$ under the overpotential of $230 \mathrm{mV}$ $\left(15 \mathrm{~mA} \mathrm{~cm}^{-2}\right)$.

$\mathrm{Co}_{0.25} \mathrm{Fe}_{0.75} \mathrm{P} \quad\left(75.0 \mathrm{mV} \quad \operatorname{dec}^{-1}\right), \quad$ and $\quad \mathrm{Co}_{0.5} \mathrm{Fe}_{0.5} \mathrm{P}$ $\left(63.4 \mathrm{mV} \mathrm{dec}^{-1}\right)$, manifesting the superior rapid HER rates of $\mathrm{Co}_{0.75} \mathrm{Fe}_{0.25} \mathrm{P}$ (Fig. 4c). Additionally, the durability of the most active $\mathrm{Co}_{0.75} \mathrm{Fe}_{0.25} \mathrm{P}$ was evaluated by $i-t$ measurement for $18 \mathrm{~h}$ (Fig. $4 \mathrm{~d}$ ). The current density vibrates at the initial stage, then presents an increment and finally maintains around $-15 \mathrm{~mA} \mathrm{~cm}^{-2}$ (overpotential: $230 \mathrm{mV}$ ) in the long-term electrocatalysis test, which suggests that the $\mathrm{Co}_{0.75} \mathrm{Fe}_{0.25} \mathrm{P}$ can also exhibit an excellent stability in the HER process.

Inspired by the outstanding catalytic activity and durability of the $\mathrm{Co}_{0.75} \mathrm{Fe}_{0.25} \mathrm{P}$ for both OER and HER, the water electrolysis activity of the $\mathrm{Co}_{0.75} \mathrm{Fe}_{0.25} \mathrm{P}$ was further evaluated by using two-electrode configurations in $1 \mathrm{~mol} \mathrm{~L}^{-1} \mathrm{KOH}$ electrolyte. As revealed in Fig. $5 \mathrm{a}, \mathrm{Co}_{0.75^{-}}$ $\mathrm{Fe}_{0.25} \mathrm{P} \| \mathrm{Co}_{0.75} \mathrm{Fe}_{0.25} \mathrm{P}$ electrolyzer only needs a low cell voltage of $1.63 \mathrm{~V}$ to achieve $10 \mathrm{~mA} \mathrm{~cm}^{-2}$, slightly higher than that of $\mathrm{RuO}_{2} \| \mathrm{Pt} / \mathrm{C}\left(1.59 \mathrm{~V} @ 10 \mathrm{~mA} \mathrm{~cm}^{-2}\right)$. It is no doubt that such relative low potential represents the best level among the state-of-art catalysts previously reported (Table S3). The durability of electrode was evaluated by $i$ $t$ test in $1 \mathrm{~mol} \mathrm{~L}^{-1} \mathrm{KOH}$ for $18 \mathrm{~h}$, many bubbles can be observed on the surface of anode and cathode during the test. As displayed in Fig. 5b, the current density does not fluctuate significantly at $10 \mathrm{~mA} \mathrm{~cm}^{-2}$ for at least $18 \mathrm{~h}$,
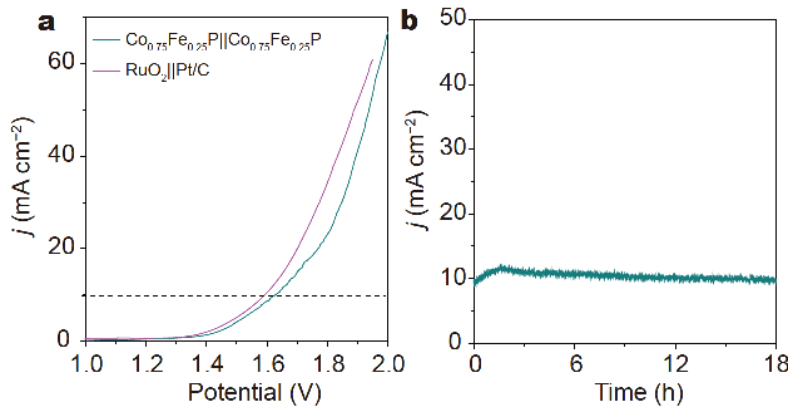

Figure 5 (a) Polarization curves of $\mathrm{Co}_{0.75} \mathrm{Fe}_{0.25} \mathrm{P} \| \mathrm{Co}_{0.75} \mathrm{Fe}_{0.25} \mathrm{P}$ and $\mathrm{RuO}_{2} \| \mathrm{Pt} / \mathrm{C}$ two electrode system in $1 \mathrm{~mol} \mathrm{~L}^{-1} \mathrm{KOH}$ for overall water splitting. (b) $i$ - $t$ curves of $\mathrm{Co}_{0.75} \mathrm{Fe}_{0.25} \mathrm{P}_{\| \mathrm{Co}_{0.75}} \mathrm{Fe}_{0.25} \mathrm{P}$ at the current density of $10 \mathrm{~mA} \mathrm{~cm}^{-2}$ in $1 \mathrm{~mol} \mathrm{~L}^{-1} \mathrm{KOH}$.

indicating that the $\mathrm{Co}_{0.75} \mathrm{Fe}_{0.25} \mathrm{P}$ electrode has an exceptional long-term stability. After the durability test, TEM measurements were applied to characterize the $\mathrm{Co}_{0.75^{-}}$ $\mathrm{Fe}_{0.25} \mathrm{P}$ electrode. As shown in Fig. S4a and S4b, the 3D ordered mesoporous structure of $\mathrm{Co}_{0.75} \mathrm{Fe}_{0.25} \mathrm{P}$ are maintained after the longtime stability test.

\section{CONCLUSION}

In summary, $3 \mathrm{D}$ ordered mesoporous $\mathrm{Co}_{1-x} \mathrm{Fe}_{x} \mathrm{P}$ electrocatalyst has been successfully developed by a simple route 
through structural and compositional control. The optimized $\mathrm{Co}_{0.75} \mathrm{Fe}_{0.25} \mathrm{P}$ shows excellent electrocatalytic OER and HER activities with low overpotentials of 270 and $209 \mathrm{mV}$ at $10 \mathrm{~mA} \mathrm{~cm}^{-2}$ and Tafel slopes of 48.2 and $55.5 \mathrm{mV} \mathrm{dec}^{-1}$ in alkaline media, respectively, along with a durable electrochemical stability. Moreover, no matter used as the cathode or anode, the $\mathrm{Co}_{0.75} \mathrm{Fe}_{0.25} \mathrm{P}$ also presented exceptional water electrolysis performance with an applied voltage of $1.63 \mathrm{~V}$, yielding a current density of $10 \mathrm{~mA} \mathrm{~cm}^{-2}$ with outstanding stability for $18 \mathrm{~h}$. This work offers a new tactic for the design and development of energy-efficient, stable, and 3D ordered mesoporous bimetal phosphides electrocatalysts for overall water splitting.

\section{Received 12 July 2019; accepted 27 August 2019; published online 17 September 2019}

1 Zhu YP, Ma TY, Jaroniec M, et al. Self-templating synthesis of hollow $\mathrm{Co}_{3} \mathrm{O}_{4}$ microtube arrays for highly efficient water electrolysis. Angew Chem Int Ed, 2017, 56: 1324-1328

2 Zhang G, Wang G, Liu Y, et al. Highly active and stable catalysts of phytic acid-derivative transition metal phosphides for full water splitting. J Am Chem Soc, 2016, 138: 14686-14693

3 Jia Y, Zhang L, Gao G, et al. A heterostructure coupling of exfoliated $\mathrm{Ni}-\mathrm{Fe}$ hydroxide nanosheet and defective graphene as a bifunctional electrocatalyst for overall water splitting. Adv Mater, 2017, 29: 1700017

4 Zhu Y, Zhou W, Zhong Y, et al. A perovskite nanorod as bifunctional electrocatalyst for overall water splitting. Adv Energy Mater, 2017, 7: 1602122

5 Song J, Xiang J, Mu C, et al. Facile synthesis and excellent electrochemical performance of CoP nanowire on carbon cloth as bifunctional electrode for hydrogen evolution reaction and supercapacitor. Sci China Mater, 2017, 60: 1179-1186

6 Feng L, Xue H. Advances in transition-metal phosphide applications in electrochemical energy storage and catalysis. ChemElectroChem, 2017, 4: 20-34

7 Song J, Zhu C, Xu BZ, et al. Bimetallic cobalt-based phosphide zeolitic imidazolate framework: $\operatorname{CoP}_{x}$ phase-dependent electrical conductivity and hydrogen atom adsorption energy for efficient overall water splitting. Adv Energy Mater, 2017, 7: 1601555

8 Han L, Dong S, Wang E. Transition-metal (Co, Ni, and $\mathrm{Fe})$-based electrocatalysts for the water oxidation reaction. Adv Mater, 2016, 28: 9266-9291

9 Zhu H, Zhang J, Yanzhang R, et al. When cubic cobalt sulfide meets layered molybdenum disulfide: A core-shell system toward synergetic electrocatalytic water splitting. Adv Mater, 2015, 27: 4752-4759

10 Liu H, Ma FX, Xu CY, et al. Sulfurizing-induced hollowing of $\mathrm{Co}_{9} \mathrm{~S}_{8}$ microplates with nanosheet units for highly efficient water oxidation. ACS Appl Mater Interfaces, 2017, 9: 11634-11641

11 Wang B, Tang C, Wang HF, et al. Anion-regulated hydroxysulfide monoliths as OER/ORR/HER electrocatalysts and their applications in self-powered electrochemical water splitting. Small Methods, 2018, 2: 1800055
$12 \mathrm{Wu} \mathrm{R}$, Xiao B, Gao Q, et al. A Janus nickel cobalt phosphide catalyst for high-efficiency neutral-pH water splitting. Angew Chem Int Ed, 2018, 57: 15445-15449

13 Zou Z, Mahmood N, Zhang Y, et al. CoP nanoparticles embedded in $\mathrm{P}$ and $\mathrm{N}$ co-doped carbon as efficient bifunctional electrocatalyst for water splitting. J Energy Chem, 2017, 26: 1223-1230

14 Fang Z, Peng L, Qian Y, et al. Dual tuning of Ni-Co-A (A = P, Se, $\mathrm{O})$ nanosheets by anion substitution and holey engineering for efficient hydrogen evolution. J Am Chem Soc, 2018, 140: 52415247

15 Zheng XR, Cao YH, Han XP, et al. Pt embedded $\mathrm{Ni}_{3} \mathrm{Se}_{2} @ \mathrm{NiOOH}$ core-shell dendrite-like nanoarrays on nickel foam as bifunctional electrocatalysts for overall water splitting. Sci China Mater, 2019, 62: 1096-1104

16 Han B, Grimaud A, Giordano L, et al. Iron-based perovskites for catalyzing oxygen evolution reaction. J Phys Chem C, 2018, 122: 8445-8454

17 Zhang R, Russo PA, Buzanich AG, et al. Hybrid organic-inorganic transition-metal phosphonates as precursors for water oxidation electrocatalysts. Adv Funct Mater, 2017, 27: 1703158

18 Qiu B, Cai L, Wang Y, et al. Fabrication of nickel-cobalt bimetal phosphide nanocages for enhanced oxygen evolution catalysis. Adv Funct Mater, 2018, 28: 1706008

19 Wang M, Dong CL, Huang YC, et al. Electronic structure evolution in tricomponent metal phosphides with reduced activation energy for efficient electrocatalytic oxygen evolution. Small, 2018, 14: 1801756

20 Wang $\mathrm{M}$, Lin $\mathrm{M}$, Li J, et al. Metal-organic framework derived carbon-confined $\mathrm{Ni}_{2} \mathrm{P}$ nanocrystals supported on graphene for an efficient oxygen evolution reaction. Chem Commun, 2017, 53: 8372-8375

21 Wang X, Chen Y, Yu B, et al. Hierarchically porous W-doped CoP nanoflake arrays as highly efficient and stable electrocatalyst for pH-universal hydrogen evolution. Small, 2019, 6: 1902613

$22 \mathrm{Hu} \mathrm{X}$, Zhang S, Sun J, et al. 2D Fe-containing cobalt phosphide/ cobalt oxide lateral heterostructure with enhanced activity for oxygen evolution reaction. Nano Energy, 2019, 56: 109-117

23 Zhang $\mathrm{X}, \mathrm{Li} \mathrm{J}$, Yang $\mathrm{Y}$, et al. $\mathrm{Co}_{3} \mathrm{O}_{4} / \mathrm{Fe}_{0.33} \mathrm{Co}_{0.66} \mathrm{P}$ interface nanowire for enhancing water oxidation catalysis at high current density. Adv Mater, 2018, 30: 1803551

24 Pan Y, Sun K, Lin Y, et al. Electronic structure and d-band center control engineering over $\mathrm{M}$-doped $\mathrm{CoP}(\mathrm{M}=\mathrm{Ni}, \mathrm{Mn}, \mathrm{Fe})$ hollow polyhedron frames for boosting hydrogen production. Nano Energy, 2019, 56: 411-419

25 Ge Y, Dong P, Craig SR, et al. Transforming nickel hydroxide into 3D Prussian Blue analogue array to obtain $\mathrm{Ni}_{2} \mathrm{P} / \mathrm{Fe}_{2} \mathrm{P}$ for efficient hydrogen evolution reaction. Adv Energy Mater, 2018, 8: 1800484

26 Zhang Y, Shao Q, Pi Y, et al. A cost-efficient bifunctional ultrathin nanosheets array for electrochemical overall water splitting. Small, 2017, 13: 1700355

27 Zeng L, Sun $\mathrm{K}$, Wang $\mathrm{X}$, et al. Three-dimensional-networked $\mathrm{Ni}_{2} \mathrm{P} /$ $\mathrm{Ni}_{3} \mathrm{~S}_{2}$ heteronanoflake arrays for highly enhanced electrochemical overall-water-splitting activity. Nano Energy, 2018, 51: 26-36

28 Zhang X, Shao J, Huang W, et al. Three dimensional carbon substrate materials for electrolysis of water. Sci China Mater, 2018, 61: 1143-1153

29 Cheng X, Pan Z, Lei C, et al. A strongly coupled 3D ternary $\mathrm{Fe}_{2} \mathrm{O}_{3} @ \mathrm{Ni}_{2} \mathrm{P} / \mathrm{Ni}\left(\mathrm{PO}_{3}\right)_{2}$ hybrid for enhanced electrocatalytic oxygen evolution at ultra-high current densities. J Mater Chem A, 2019, 7: 965-971 
30 Fan L, Zhang $\mathrm{P}$, Zhang B, et al. 3D core-shell NiFeCr catalyst on a $\mathrm{Cu}$ nanoarray for water oxidation: Synergy between structural and electronic modulation. ACS Energy Lett, 2018, 3: 2865-2874

31 Zhou Q, Pu J, Sun X, et al. In situ surface engineering of nickel inverse opal for enhanced overall electrocatalytic water splitting. J Mater Chem A, 2017, 5: 14873-14880

32 Pan Y, Sun K, Liu S, et al. Core-shell ZIF-8@ZIF-67-derived CoP nanoparticle-embedded $\mathrm{N}$-doped carbon nanotube hollow polyhedron for efficient overall water splitting. J Am Chem Soc, 2018, 140: $2610-2618$

33 Liu ZQ, Cheng $\mathrm{H}$, Li N, et al. $\mathrm{ZnCo}_{2} \mathrm{O}_{4}$ quantum dots anchored on nitrogen-doped carbon nanotubes as reversible oxygen reduction/ evolution electrocatalysts. Adv Mater, 2016, 28: 3777-3784

34 Liu Q, Tian J, Cui W, et al. Carbon nanotubes decorated with CoP nanocrystals: A highly active non-noble-metal nanohybrid electrocatalyst for hydrogen evolution. Angew Chem Int Ed, 2014, 53: 6710-6714

$35 \mathrm{Kim} \mathrm{OH}$, Cho $\mathrm{YH}$, Kang SH, et al. Ordered macroporous platinum electrode and enhanced mass transfer in fuel cells using inverse opal structure. Nat Commun, 2013, 4: 2473

36 Deng X, Chen K, Tüysüz H. Protocol for the nanocasting method: Preparation of ordered mesoporous metal oxides. Chem Mater, 2017, 29: 40-52

37 Cho JM, Lee SR, Sun J, et al. Highly ordered mesoporous $\mathrm{Fe}_{2} \mathrm{O}_{3}-$ $\mathrm{ZrO}_{2}$ bimetal oxides for an enhanced $\mathrm{CO}$ hydrogenation activity to hydrocarbons with their structural stability. ACS Catal, 2017, 7: 5955-5964

38 Xiao C, Zhang X, Mendes T, et al. Highly ordered hierarchical mesoporous $\mathrm{MnCo}_{2} \mathrm{O}_{4}$ with cubic $I \alpha 3 d$ symmetry for electrochemical energy storage. J Phys Chem C, 2016, 120: 23976-23983

39 Park GO, Yoon J, Park SB, et al. Nanostructural uniformity of ordered mesoporous materials: Governing lithium storage behaviors. Small, 2017, 14: 1702985

40 Wang Y, Zhao H, Li M, et al. Magnetic ordered mesoporous copper ferrite as a heterogeneous Fenton catalyst for the degradation of imidacloprid. Appl Catal B-Environ, 2014, 147: 534545

41 Zhu W, Zhang W, Li Y, et al. Energy-efficient 1.67 V single- and $0.90 \mathrm{~V}$ dual-electrolyte based overall water-electrolysis devices enabled by a ZIF-L derived acid-base bifunctional cobalt phosphide nanoarray. J Mater Chem A, 2018, 6: 24277-24284

42 Lin Y, Yang L, Zhang Y, et al. Defective carbon-CoP nanoparticles hybrids with interfacial charges polarization for efficient bifunctional oxygen electrocatalysis. Adv Energy Mater, 2018, 8: 1703623

43 Lu Y, Hou W, Yang D, et al. CoP nanosheets in-situ grown on Ndoped graphene as an efficient and stable bifunctional electrocatalyst for hydrogen and oxygen evolution reactions. Electrochim Acta, 2019, 307: 543-552

44 Chen J, Liu J, Xie JQ, et al. Co-Fe-P nanotubes electrocatalysts derived from metal-organic frameworks for efficient hydrogen evolution reaction under wide $\mathrm{pH}$ range. Nano Energy, 2019, 56: 225-233

45 Li Y, Liu J, Chen C, et al. Preparation of NiCoP hollow quasipolyhedra and their electrocatalytic properties for hydrogen evolution in alkaline solution. ACS Appl Mater Interfaces, 2017, 9: 5982-5991

46 Wang $\mathrm{H}$, Wang $\mathrm{X}$, Zheng $\mathrm{B}$, et al. Self-assembled $\mathrm{Ni}_{2} \mathrm{P} / \mathrm{FeP}$ heterostructural nanoparticles embedded in $\mathrm{N}$-doped graphene nanosheets as highly efficient and stable multifunctional electrocatalyst for water splitting. Electrochim Acta, 2019, 318:
449-459

47 Cui W, Liu Q, Xing Z, et al. MoP nanosheets supported on biomass-derived carbon flake: One-step facile preparation and application as a novel high-active electrocatalyst toward hydrogen evolution reaction. Appl Catal B-Environ, 2015, 164: 144-150

48 Yang D, Hou W, Lu Y, et al. Scalable synthesis of self-assembled bimetallic phosphide/N-doped graphene nanoflakes as an efficient electrocatalyst for overall water splitting. Nanoscale, 2019, 11: 12837-12845

49 Yang D, Hou W, Lu Y, et al. Scalable synthesis of bimetallic phosphide decorated in carbon nanotube network as multifunctional electrocatalyst for water splitting. ACS Sustain Chem Eng, 2019, 7: 13031-13040

50 Qian Q, Li Y, Liu Y, et al. Ambient fast synthesis and active sites deciphering of hierarchical foam-like trimetal-organic framework nanostructures as a platform for highly efficient oxygen evolution electrocatalysis. Adv Mater, 2019, 31: 1901139

51 Pramanik M, Li C, Imura M, et al. Ordered mesoporous cobalt phosphate with crystallized walls toward highly active water oxidation electrocatalysts. Small, 2016, 12: 1709-1715

52 Guan C, Xiao W, Wu H, et al. Hollow Mo-doped CoP nanoarrays for efficient overall water splitting. Nano Energy, 2018, 48: 73-80

Acknowledgements This work was supported by the National Natural Science Foundation of China (51571072 and 51871078) and Heilongjiang Science Foundation (E2018028).

Author contributions Huang Y, Yang $\mathrm{W}$ and Yu Y designed the research. Huang Y fabricated the materials, analyzed the results, and wrote the manuscript with support from Li M and Hao S. Yu Y and Yang W supervised the project and revised the manuscript. All authors contributed to the general discussion.

Conflict of interest The authors declare no conflict of interest.

Supplementary information Supporting data are available in the online version of this paper.

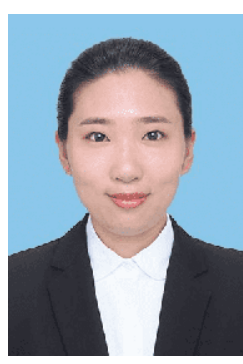

Yarong Huang received her Master's degree from Inner Mongolia University of Technology in 2015. Currently, she is a $\mathrm{PhD}$ candidate at the School of Chemistry and Chemical Engineering, Harbin Institute of Technology. Her current research interest focuses on the synthesis and design of mesoporous materials for electrocatalysis.

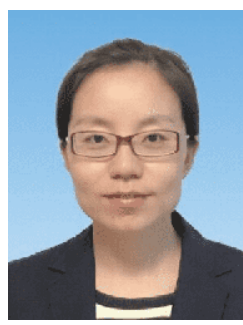

Weiwei Yang earned her $\mathrm{PhD}$ in chemistry from Jilin University in 2008. Then, she worked at the University of Nebraska-Lincoln (2008-2011) as a postdoctoral researcher and Brown University (2012-2013) as a visiting scholar. She joined Harbin Institute of Technology in 2012. Now she is an Associate Professor of the School of Chemistry and Chemical Engineering. Her research interests include the design and synthesis of functional nanoparticles, and their electrochemical and energy-related applications. 


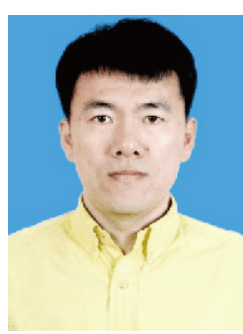

Yongsheng $\mathrm{Yu}$ received his $\mathrm{PhD}$ in materials chemistry and physics from Harbin Institute of Technology in 2010. He was a postdoctoral researcher at Brown University (2011-2013) and University of Nebraska-Lincoln (2013-2014), respectively. He joined the School of Chemistry and Chemical Engineering of Harbin Institute of Technology in 2014 as a Professor. His research interests are in nanomaterials synthesis, self-assembly, and applications in catalysis and energy storage.

\section{三维有序介孔钴铁磷化物在全解水中的应用}

黄雅荣, 李蒙刚, 杨微微 ${ }^{*}$, 于永生 ${ }^{*}$, 郝素娥

摘要 构筑低成本、资源丰富、高效的电化学全解水催化剂是目 前一个极具挑战的课题. 本文报道了一种简便高效地制备三维有 序介孔 $\mathrm{Co}_{1-x} \mathrm{Fe}_{x} \mathrm{P}(x=0,0.25,0.5,0.75)$ 电催化剂的方法. 得益于三 维有序介孔孔道和成分的优化, $\mathrm{Co}_{0.75} \mathrm{Fe}_{0.25} \mathrm{P}$ 催化剂在碱性电解质 中表现出优异的电催化活性, 在电流密度为 $10 \mathrm{~mA} \mathrm{~cm}^{-2}$ 下, 析氧和 析氢的过电位分别是 270 和 $209 \mathrm{mV}$, 同时该催化剂也表现出良好的 电化学稳定性. 利用 $\mathrm{Co}_{0.75} \mathrm{Fe}_{0.25} \mathrm{P}$ 催化剂作为电解水制氢的阴极和 阳极, 只需要施加 $1.63 \mathrm{~V}$ 的电压即可获得 $10 \mathrm{~mA} \mathrm{~cm}^{-2}$ 的电流密度, 并且在 $18 \mathrm{~h}$ 稳定性测试后电流密度没有出现衰减, 证明其在全解水 应用中具有优异的催化活性. 